\title{
日本における住宅の経年減価についての考察
}

民営借家の家賃統計からの推計

\section{A CONSIDERATION ABOUT AGE DEPRECIATION OF HOUSING IN JAPAN}

A projection based on statistics of age depreciation of rent in commercial rental housing

\author{
前田拓生*
}

\section{Takuo MAEDA}

\begin{abstract}
We tried to clarify whether a life of well managed housing is longer than privately-owned properties in Japan. As a result of analysis from a projection of age depreciation of rent, age depreciation rate of rental housing was more gradual than privately owned housing.

Thus the system being established by the Ministry of Land, Infrastructure, Transport and Tourism (2013) would be effective in increasing sales volume of secondhand housing market and extending a service life of housing in Japan.
\end{abstract}

Keywords : age depreciation, market of resale housing, a service life of housing, maintenance 経年減価，中古住宅市場. 住宅の寿命，メンテナンス

\section{1. はじめに}

内閣府 1)によると、欧米諸国では住宅取引件数に占める既存住宅 の割合が相対的に高く、特に米国では 9 割近くが既存住宅の取引で ある一方、日本は新築住宅がほとんどであり、既存住宅の取引は 1 割強に留まっている注 1)。最近は既存住宅の取引が日本でも増加しつ つあるとは言われているが、統計的には現在も大きな変化はみられ ない注 2)。日本において既存住宅の取引が少ない背景について内閣府 1) は日本の住宅の滅失住宅の平均築後年数が欧米に比べて短いこと を挙げている。実際、日本の住宅は米国に比べて築年数の長い住宅 のストックの割合が少ない（Fig.1）。
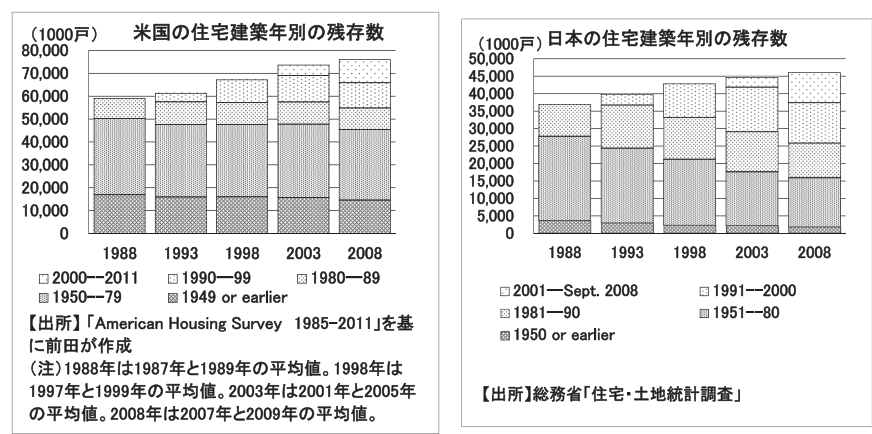

Fig. 1 Residual number of housing (left :US, right : Japan)
この点に関して国土交通省 2)では以下のように分析している。日本 の建物は一律に経年減価させる形で原価法により評価されていて、 減価修正に用いる耐用年数の設定において税法上の耐用年数等を参 考にしている。そのために実際の耐久性能とは関係なく、税法上の 耐用年数を超える住宅は価值「0」として取引されている。同様に 前田 ${ }^{3)}$ においても既存住宅の所有者が当該住宅を売却しようにも税 法上の耐用年数を超える住宅の場合には価值「0」と評価される問 題を指摘している。既存住宅が適正に評価されないために、住宅所 有者は住宅価值を高めるためのメンテナンス等を積極的に行うイン センティブを失う。メンテナンス等をしない世帯が多く、住宅の品 質に対する情報インフラ等が整備されていない場合、既存住宅を売 却しょうとしても、住宅購入者は Lemon（不良品）と Peach（適切 な品質なもの）の区別ができないことから適切に価格付けすること

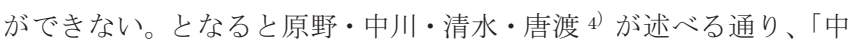
古 (既存) 住宅取引時点で評価される価值は土地のみ注3)」となる。 さらに既存住宅が市場で取引されず、既存住宅の適正価值が評価さ れないとなると、既存住宅における取引では金融機関も住宅そのも のを担保とする貸し付けが困難になる。そのために住宅購入者は資 金的な手当てに笨することとなり、一定年数以上経過した築古の既 存住宅は市場の取引対象とはならず、所有者にとって不要になった 既存住宅は市場での売却を諦め、更地にして売却するか、空き家の まま放置されることになる。

以上のように日本の住宅の寿命が短いのは、住宅市場において税

\footnotetext{
* 早稲田大学理工学研究所 招聘研究員・修士(経営学)
} 
法上の耐用年数等を参考に取引されていることが原因であると推測 されるが、そもそも日本の住宅市場では個々の住宅の本質的な価值 を市場が適切に評価するシステムが整っていないことも大きな問題 であると言える。そこで前掲国土交通省 2) では、築 30 年を超える 築古の賃貸住宅であっても実際の賃貸住宅市場においてはその使用 価值を認めて市場価值が付いている（家貨を受け取れている）こと に注目し、原価法を抜本的に改善し、建物評価の適正化を図るため に「リフォーム等により手をかけた住宅が適切に評価されるよう、 築年数のみによらず、住宅の使用価值を適切に反映した評価手法一 の改善を図る」ことを提言している。つまり、築年数で一律に価格 が評価されるのではなく、メンテナンス等を行った住宅はその性能 に応じた価格で評価がなされる仕組みに改善するということである。 このような制度を導入することによって住宅の本質的な価值を市場 が適切に評価でき、既存住宅の売買も促進される可能性があること から、意義のあることだといえる。

しかし、山崎 5) はアンケート調查等によって「米国では経年的減 価意識が低く、投資によって価值の増幅を期待する違いがあること、 故に米国では古い住宅にも投資の期待をかける傾向」があるものの、 「日本は経年的に価值の減衰を避けられないとみる住宅寿命観が非 常に強いこと」注 4）を明かにしている。このような「住宅寿命観」 が存在するとした場合、原価法を抜本的に改善し、建物評価の適正 化を図ってリフォーム等を促しても、住宅市場の参加者は「適正な 価值」を受け入れず、築古の住宅に対しては従来通りの（税法上の 耐用年数に依存した）評価しか与えない可能性がある。この䋅念を 払しょくするためにはメンテナンス等を行うことによって住宅の経 年減価が緩和されることを、日本の住宅市場においても示寸必要が あろう。

現状の住宅における経年減価についてはクー/佐々木 ${ }^{6}$ )が実際の 住宅物件の売買価格を使って推計を行っている。この推計によれば、 マンションも戸建住宅も約 15 年で建物部分の経済的価值（住宅価 格）は失われることになる。この結果は税法上の耐用年数等を参考 しつつ、メンテナンス等に消極的な現在の日本の住宅事情を考慮す れば、概ね妥当な結果である。他方、メンテナンス等を行っている と市場が認識する住宅に特化した住宅の経年減価状況については推 計されていない。メンテナンス等を行っている住宅だけに特化した 既存住宅の価格情報を入手することは実際には困難であるが、前掲 国土交通省 2) の通りであれば、賃貸住宅の場合、業として事業を継 続していくためにも一定程度のメンテナンス等は随時行っているこ とになり、住宅の市場参加者もそのように認識しているという仮定 をおくことができる。とはいえ、やはり既存の賃貸住宅に絞っても、 その建築時期別の個別の価格情報を得ることは困難である注 5)。

そこで本論文では、総務省 7)「住宅土地統計調查（以下、住宅土 地統計)」の民営借家の家賃統計を基に当該住宅における経年減価の 推計を行った。当該統計では 5 年ごとに日本の住宅とそこに居住す る世帯の居住状況、世帯の保有する土地等の実態を調查している。 この中で築年数別・入居時期別等の家貨状況が都道府県別に取得で きる。しかし、実際の家賃は築年数（つまり、経年による違い）の 他にも利便性等（駅や公共施設からの距離等）によって金額が異な る。住宅土地統計でも全数調查を行っているのではないので、統計 上の誤差を含んでいるものの、一定の誤差注 6)を容認すれば、マク
口的な意味で家賃の経年減価を推計することができる。

以下、本論文は次のような構成になっている。本論文では家賃統 計から住宅の経年減価を推計することを目的としているが、フロー としての家賃はストックとしての住宅（建物部分、以下同様）と土 地の収益力から産み出されるものと仮定して推計することにした。 その際、住宅の収益力に帰属寸る部分と土地の収益力に帰属する部 分に按分する必要がある。 2 章ではこの按分に関する推計を行う。2 章の推計結果を利用して 3 章で家賃統計から住宅の経年減価の推計 を行い、4 章で総括する

\section{2. 家賃のうち住宅価格に帰属する部分についての推計}

(1) 家貨と住宅価格の関係

本論文では家顀統計から住宅の経年減価を推計することを目的に しているので、まず、家賃と住宅価格の関係を考察する。ここでは 収益還元法のうち Discounted Cash Flow 法（DCF 法）を用いて住 宅価格が決定されるものと仮定する。DCF 法では予測可能な連続す る期間を保有期間とし、当該期間に発生するキャッシュフローの現 在価值と当該期間終了時点の当該住宅の価格（復帰価格）の現在価 值を合計して住宅価格とすることが一般的である。しかし、本論文 では復帰価格を考えずに、税法上の耐用年数を保有期間として、そ の間に発生するキャッシュフローの現在価值の総額を住宅価格とす る。

$$
\begin{aligned}
A_{t} & =R+R /(1+r)+R /(1+r)^{2}+\cdots+R /(1+r)^{t^{-}}+R /(1+r)^{t^{-1}} \\
& =R \times\left((1+r)^{t-1) / r(1+r)^{t^{-} 1}} \cdots(1)\right.
\end{aligned}
$$

但し、 $A_{t}$ : 耐用年数 $t$ 年の住宅価格、 $R$ : 家賃、 $r$ : 割引率。

ここで 1 年経過した時の当該住宅の住宅価格は以下の通りである。

$$
\begin{aligned}
A_{t+1} & =R \times((1+r) t-1) / r(1+r)^{t^{-}}-R /(1+r)^{t^{-}} 1 \\
& =R \times\left((1+r)^{t-1}-r\right) / r(1+r)^{t^{-1}}
\end{aligned}
$$

しかし、この 1 年の間に資本的支出によってメンテナンスを行っ た場合、当該メンテナンスに要した金額（I）だけ住宅価格は上昇す ることになる。

$$
A_{t+1}=R \times\left((1+r)^{t}-1-r\right) / r(1+r)^{t^{-}}+1
$$

したがって、住宅価格の 1 年間の経年減価率を $x_{A}$ とした場合、以 下のようになる。

$$
\begin{aligned}
& A_{t} \times X_{A}=A_{t+1} \\
& X_{A}=1-r /\left((1+r)^{t^{-}} 1\right)+I / R \times r(1+r)^{t^{-}} 1 /\left((1+r)^{t-1}\right) \quad \cdots(4)
\end{aligned}
$$

ここで資本的支出によってメンテナンスを行った場合、当該メン テナンスによって増えた分における耐用年数は住宅本体の当初の耐 用年数と同じである。つまり、メンテナンスを継続して行っている 住宅の耐用年数は、築年数に関わりなく、メンテナンスを行った時 点から改めて当初の耐久年数が加算されるので、メンテナンスを行 うことによってメンテナンス部分を含めた住宅本体の耐用年数は長 
くなる。但し、メンテナンスによる価格の増加分よりも経年による 価格の低下分の方が大きい（メンテナンスはあくまでも修繥なので 経年劣化を超えて価格を向上させることはない) ので、経年減価が 生じることになる。そこで、保有期間を通じて家賃の金額が変化し ないと仮定するモデルではなく、家貨も経年減価すると仮定した場 合、家賃の 1 年間の経年減価率を $x_{R}$ とすると以下の関係が成り立つ。

$$
\begin{aligned}
& A_{t}=R_{t} \times\left((1+r)^{t-1}\right) / r(1+r)^{t-1} \\
& A_{t+1}=R_{t+1} \times\left((1+r)^{t-1}\right) / r(1+r)^{t^{-1}} \\
& R_{t} \times \mathrm{x}_{R}=R_{t+1}
\end{aligned}
$$

ここで 1 年間の住宅価格の低下は以下のように計算できる。

$$
\begin{gathered}
\left(R_{t}-R_{t} \times X_{R}\right) \times\left((1+r)^{t}-1\right) / r(1+r)^{t^{-1}}=R_{t} /(1+r)^{t^{-}}-I-I \\
X_{R}=1-r /\left((1+r)^{t^{-}} 1\right)+I / R_{t} \times r(1+r)^{t^{-}} 1 /\left((1+r)^{t-1}\right) \quad \cdots(6)
\end{gathered}
$$

以上(4)と(6)から、メンテナンスを継続して行っている住宅の場合 には、築年数に関わらず、いずれの時点でも耐用年数は一定となる ことから、家賃も経年減価すると仮定すれば、その経年減価率は家 賃の場合も住宅の場合も同じ值を取る。

とはいえ、家顀は住宅だけではなく、土地の影響も受ける。

(2) 家貨のうち住宅価格に帰属する部分

そこでここでは、名目家賃は当該住宅と土地の収益力それぞれに よってもたらされると仮定する。

$$
p R_{t}=a A_{t}+I L
$$

但し、 $p:$ 物価、 $a$ : 住宅の名目収益率、 $l:$ 土地の名目収益率、 $L:$ 土地の価格。

(7)式を全微分すると以下のようになる。

$$
\begin{aligned}
& p \mathrm{~d} R_{t}=a \mathrm{~d} A_{t}+l \mathrm{~d} L \\
& \mathrm{~d} R_{t} / R t=\operatorname{ad} A_{t} p R_{t}+l \mathrm{~d} L / p R_{t}
\end{aligned}
$$

なお、(7)式の両辺を $p R_{t}$ で割ることによって家賃のうち住宅の収 益力に起因する割合（家賃のうち住宅価格に帰属する部分）と土地 の収益力に起因する割合を表すことができる（下記(9)式)。

$$
1=a A_{t} p R_{t}+I L / p R_{t}
$$

(9)式の右辺第 1 項 $\left(a A_{t} t p R_{t}\right)$ が家賃のうち住宅価格に帰属する 部分 $\left(y_{1}\right)$ であり、同第 2 項 $\left(I L / p R_{t}\right)$ が家賃のうち土地価格に帰 属する部分 $\left(y_{2}\right)$ である。

この関係から(8)式は以下のように表すことができる。

$$
\mathrm{d} R_{t} / R_{t}=y_{1} \times \mathrm{d} A_{t} / A_{t}+y_{2} \times \mathrm{d} L / L
$$

ところで、対数の微分により、以下の関係が成り立つ。

$$
\Delta \mathrm{LN}(Z)=\mathrm{d} Z / Z
$$

(11)式の関係から(10)式は以下のように書き換えることができる。

$$
\Delta \mathrm{LN}\left(R_{t}\right)=y_{1} \times \Delta \mathrm{LN}\left(A_{t}\right)+y_{2} \times \Delta \mathrm{LN}(L) \quad \cdots(12)
$$

ここで、 $R_{t}=R \times \operatorname{EXP}\left(-x_{R} t\right) 、 A_{t}=A \times \operatorname{EXP}\left(-x_{A} t\right)$ とすると、以下 のようになる (築年数差を $\Delta t$ とする)。

$$
x_{R} \Delta t=y_{1} \times_{X_{A}} \Delta t
$$

(13)式より、家貨のうち住宅価格に帰属する部分 $y_{1}$ がわかれば、 当該住宅の経年減価率を推計することができる。

ここで(12)式は(9)式 $\left(1=y_{1}+y_{2}\right)$ の関係から以下のようになる。

$$
\Delta \mathrm{LN}(R t / L)=y_{1} \Delta \mathrm{LN}(A t / L)
$$

以上から(14)式を実証することによって $y_{1}$ を求めることができる。 そこで(14)式を以下で実証するが、(14)式を実証するために、次の ようなデータを取得した。

家賃については住宅土地統計から都道府県別に住宅の種類（専用 住宅、店舗等) 別、専用住宅の所有の関係（公営の借家、民営借家 (木造/非木造) 等) 別、建築の時期別に家賃データを取得できる。 住宅土地統計は 5 年ごとに発行されている。本論文で分析対象にし たのは平成 10 年、平成 15 年、平成 20 年及び平成 25 年の 4 つの統 計である。

ここでクー/佐々木 ${ }^{6}$ )が推計した一般住宅の経年減価の状況と比 較させることが目的なので、専用住宅の民営借家（木造及び非木造 の別）の家賃（1畳（1.65m²) あたり）を使用し、後述の住宅 1 戸 あたりの床面積を掛け合わせることで民営借家 1 戸あたりの家賃を 推計した。但し、都道府県別の統計では入居時期については分類さ れていないことから、新築時の家賃としては各年の統計調査におい て最も新しい建築時期の家賃を新築時の家賃として使用する。具体 的には平成 10 年統計では 1996 年から 1998 年の間、平成 15 年統 計では 2001 年から 2003 年の間、平成 20 年統計では 2006 年から 2008 年の間、平成 25 年統計では 2011 年から 2013 年の間にそれぞ れ入居した時の家賃が記されているので、その值を使っている。し たがって、以下において住宅価格及び地価に関するデータもそれぞ れの年に合わせて集計した。なお、家賃に関しての実質化には総務 省 ${ }^{8}$ 「「消費者物価指数（木造・非木造ともに「民営借家」：平成 17 年基準)」を使用した。

地価については一般社団法人土地情報センター9）のサイトから各 年の都道府県別の地価（都道府県地価調查）を取得した。敷地面積 については住宅土地統計から住宅の所有の関係別, 建て方（戸建、 長屋建）別の 1 住宅当たり敷地面積を取得できる。専用住宅（戸建 と長屋建を合計した值注 7) の民営借家の敷地面積を使用し、敷地面 積に当該地価を掛け合わせて住宅 1 戸あたりの地価とした（家賃デ ータの年データに合わせるために各年の地価を実質化したうえで平 均化した)。なお、実質化には内閣府 10）「国民経済計算 (SNA 統計)」 の住宅投資デフレーター (平成 17 年基準) を使用した。しかし、 当該統計では構造（木造及び非木造）別のデータは存在しない。 
住宅価格については国土交通省 11)「住宅着工統計調査」の月次デ ータから（「民営借家」の項目はないので）貸家について木造及び非 木造別に新築住宅戸数、床面積、工事費予定額を取得できる注8)。こ こで工事費予定額を新築住宅戸数で除すことによって住宅 1 戸あた り工事費予定額が算出できるので、その值を住宅 1 戸あたりの住宅 価格とした。なお、床面積を新築住宅戸数で除すことによって住宅 1 戸あたり床面積が算出できるので、前述の家貨データと掛け合わ せることによって住宅 1 戸あたりの家賃を算出できる。実質化には 国土交通省 ${ }^{12}$ )「建設工事費デフレーター（平成 17 年度基準の月次 データを利用して平成 17 年暦年ベースに修正・推計して)」使用し た。

ここで平成 25 年の住宅土地統計の家賃データ（2011 年～2013 年）には対応できるデータは存在するが、平成 20 年から平成 10 年 の住宅土地統計の工事費予定額等のデータは存在しない。そこで住 宅価格については、以下のように代替したデータを利用して分析を 行った。住宅 1 戸あたり延べ面積については住宅土地統計から都道 府県別、木造/非木造別に時系列で民営借家（戸建及び長屋建の合 計）のデータが取得できる。工事費予定額については $\mathrm{m}^{2}$ あたりも 住宅 1 戸あたりも都道府県別、木造/非木造別の時系列データも存 在しないが、住宅着工統計の年次データで居住専用住宅であれば、 都道府県別、木造及び非木造別に時系列で新築住宅戸数、床面積、 工事費予定額データを取得できる。本分析においてはこのデータを 利用する注9)。なお、実質化には住宅着工統計の分析と同様に建設工 事費デフレーターを使用した。

Table1 Basic descriptive statistics 用いたデータの記述統計

\begin{tabular}{|c|c|c|c|c|c|c|c|c|c|c|}
\hline \multirow{2}{*}{\multicolumn{2}{|c|}{\begin{tabular}{|l|l|}
\multicolumn{2}{|l|}{} \\
$\begin{array}{l}\text { 平米あたり家貨 } \\
\text { (チ円) }\end{array}$
\end{tabular}}} & \multicolumn{3}{|c|}{ 平均值骠準偏差最小値 } & \multicolumn{2}{|l|}{ 最大値 } & \multicolumn{3}{|c|}{ 平均値骠準偏差最小値 } & \multirow{2}{*}{$\begin{array}{r}\text { 最大值 } \\
5.1\end{array}$} \\
\hline & & 1.7 & \begin{tabular}{|l|}
0.4 \\
\end{tabular} & 0.7 & 3.6 & $\begin{array}{l}\text { 平米あたり家貨 } \\
\text { (千円) }\end{array}$ & 2.2 & 0.5 & 1.4 & \\
\hline & $\begin{array}{l}\text { 住宅1戸あたり床 } \\
\text { 面積 (m2) }\end{array}$ & 59.3 & 4.9 & 46.4 & 61.5 & $\begin{array}{l}\text { 住宅1戸あたり床 } \\
\text { 面積 }(\mathrm{m} 2)\end{array}$ & 40.5 & 2.5 & 30.2 & 47.7 \\
\hline \multirow[t]{3}{*}{ 造 } & 家貨 (千円) & 95.9 & 15.1 & 35.8 & 157.1 & 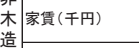 & 88.3 & 16.9 & 59.8 & 176.0 \\
\hline & 住宅価格 (千円) & $8,461.9$ & $1,218.0$ & $5,468.8$ & $11,722.1$ & 住宅価格(千円) & $6,610.2$ & 674.4 & $4,891.0$ & $8,325.9$ \\
\hline & 土地価格 (千円) & $6,144.8$ & $4,038.5$ & $2,380.1$ & $26,509.8$ & 土地価格 (千円) & $6,144.8$ & $4,038.5$ & $2,380.1$ & $26,509.8$ \\
\hline
\end{tabular}

(14)式をパネル分析する上で上記のデータ（Table1）を使って分 析を行うが、都道府県特有の観測できない変数 (クロス項) や各統 計の発行年に特有の観測できない変数（時間項）が存在することが 想定される。そこで誤差要因モデルにおいて(14)式の他、クロス固 定効果モデル、クロス変量効果モデル、時系列固定効果モデル、時 系列変量効果モデル、二方向固定効果モデル、二方向変量効果モデ ルそれぞれについて F 検定及び八ウスマン検定を行い、民営借家 (木 造及び非木造）の家賃に関して木造及び非木造ともに時系列固定効 果モデルを選択した。ともに時系列固定効果モデルなので、(14)式 を下記(15)式のモデルとしてパネル分析を行った。

$\Delta \mathrm{LN}\left(R_{P T} / L_{P T}\right)=\Delta \mathrm{LN}(\alpha)+\beta \Delta \mathrm{LN}\left(A_{P T} / L_{P T}\right)+{ }_{V T}+\varepsilon_{P T}$ $\cdot \cdot(15)$

ここで $R 、 L 、 A$ はそれぞれ(14)式と同じで、 $y_{1}=\beta$ とし、 $\Delta \mathrm{LN}(\alpha)$ は定数項である。添え字の $T$ は住宅土地統計の発行年別を示し、 $P$ は都道府県別を示す。 $V T$ は住宅土地統計の発行年の別の誤差を示し、
EPTは誤差項である。

回帰結果は Table2（1)の通りであり、民営借家（木造）の住宅価 格に帰属する部分の割合は 0.780 で、民営借家（非木造）のそれが 0.873 となった。

また、本論文では前掲国土交通省 ${ }^{2)}$ の認識に注目して、リフォー ム等を行っていると市場が認識している賃貸住宅は一般の住宅に比 べて、経年による住宅価格の低下速度が遅いと市場が評価するか否 かを検証することを目的にしている。そこで本分析では、借家とし ての競争条件が厳しいと推測される、単位当たりの土地の価格が高 い地域とその他に分けて分析を行った。

具体的には説明変数にあたる $\mathrm{LN}(A / L)$ が負の值を取った、つまり、 1 戸あたりの住宅価格（工事費予定額により推計）に比べて 1 戸あ たりの土地価格（都道府県地価調查により推計）が高い都府県 (9 都府県注 $\left.{ }^{10}\right)$ ）とその他の道県（38 道県）に分けて、それぞれ上記同 様の推計を行った。ここでもクロス固定効果モデル、クロス変量効 果モデル、時系列固定効果モデル、時系列変量効果モデル、二方向 固定効果モデル、二方向変量効果モデルそれぞれについて $\mathrm{F}$ 検定及 びハウスマン検定を行い、9 都府県の木造はクロス変量効果モデル、 非木造は時系列固定効果モデル、その他 38 道県は木造・非木造と もに時系列固定効果モデルで階差を取って分析した。

9 都府県の回帰結果は Table2 (2)の通りであり、民営借家（木造） の建物価値に帰属寸る部分の割合は 0.662 で、民営借家（非木造） のそれが 0.810 となった。また、その他 38 道県の回帰結果は Table.2 (3)の通りであり、民営借家 (木造) の建物価值に帰属する部分の割 合は 0.764 で、民営借家（非木造）のそれが 0.787 となった。

Table2 Result of regression analysis for contribution to a rent for rental housing into building

(1) All Japan (upper: wooden housing, lower: non-wooden housing) 住宅部分の家貨における割合分析 (木造住宅_全国)

\begin{tabular}{|c|c|c|c|c|}
\hline 説明変数 & 係数 & Std.E & t値 & p值 \\
\hline$\Delta \mathrm{LN}(\mathrm{a})$ & -0.019 & 0.006 & -2.966 & 0.004 \\
\hline$\Delta \mathrm{LN}(\mathrm{A} / \mathrm{L})$ & 0.780 & 0.053 & 14.843 & 0.000 \\
\hline 補正R2 & \multicolumn{4}{|l|}{0.513} \\
\hline DWE比 & \multicolumn{4}{|l|}{2.694} \\
\hline 推言cross & \multirow{2}{*}{\multicolumn{4}{|c|}{\begin{tabular}{|l|l}
3.000 \\
.000
\end{tabular}}} \\
\hline Periods & & & & \\
\hline 標準誤差の修正 & \multicolumn{4}{|c|}{ White cross-section standard errors \& covariance (d.f. corrected) } \\
\hline \multicolumn{5}{|c|}{$\begin{array}{l}\text { 住宅部分の家賃における割合分析 (非木造住宅_全国) } \\
\text { 被説明変数: } L N(R / L / L)\end{array}$} \\
\hline 説明変数 & 係数 & Std.E & t值 & $\mathrm{pp \text { 值 }}$ \\
\hline$\Delta \mathrm{LN}(\mathrm{a})$ & -0.001 & 0.011 & -0.065 & 0.949 \\
\hline$\Delta \mathrm{LN}(\mathrm{A} / \mathrm{L})$ & 0.873 & 0.102 & 8.590 & 0.000 \\
\hline 補正R2 & \multicolumn{4}{|l|}{0.612} \\
\hline DWE比 & \multicolumn{4}{|l|}{2.605} \\
\hline 推言cross & \multirow{2}{*}{\multicolumn{4}{|c|}{$\frac{47.000}{3.000}$}} \\
\hline Periods & & & & \\
\hline 標準誤差の修正 & \multicolumn{4}{|c|}{ White cross-section standard errors \& covariance (d.f. corrected) } \\
\hline
\end{tabular}

(2) 9 prefectures (upper: wooden housing, lower: non-wooden housing) 住宅部分の家賃における割合分析 (木造住宅_9都府県)

\begin{tabular}{|c|c|c|c|c|}
\hline 説明変数 & 係数 & Std.E & t值 & p值 \\
\hline$\Delta \mathrm{LN}(\mathrm{a})$ & -0.033 & 0.076 & -0.436 & 0.667 \\
\hline$\Delta \mathrm{LN}(\mathrm{A} / \mathrm{L})$ & 0.662 & 0.168 & 3.944 & 0.001 \\
\hline 補正R2 & \multicolumn{4}{|l|}{0.279} \\
\hline DW比 & \multicolumn{4}{|l|}{3.450} \\
\hline 推言cross & \multirow{2}{*}{\multicolumn{4}{|c|}{$\begin{array}{l}9.000 \\
3000\end{array}$}} \\
\hline Periods & \multicolumn{2}{|c|}{3.000} & & \\
\hline 標準誤差の修正 & \multicolumn{4}{|c|}{ Cross-sections included: 9} \\
\hline \multicolumn{5}{|c|}{$\begin{array}{l}\text { 住宅部分の家賃における割合分析 (非木造住宅_9都府県) } \\
\text { 被説明変数 } L N(R / L)\end{array}$} \\
\hline 説明変数 & 係数 & Std.E & $\mathrm{t}$ t值 & p值 \\
\hline$\Delta \mathrm{LN}(\mathrm{a})$ & -0.032 & 0.011 & -2.998 & 0.006 \\
\hline$\Delta \mathrm{LN}(\mathrm{A} / \mathrm{L})$ & 0.810 & 0.122 & 6.633 & 0.000 \\
\hline 補正R2 & \multicolumn{4}{|l|}{0.862} \\
\hline DW比 & \multicolumn{4}{|l|}{1.712} \\
\hline 推言cross & \multicolumn{4}{|l|}{9.000} \\
\hline Periods & \multicolumn{4}{|l|}{3.000} \\
\hline 標準誤差の修正 & \multicolumn{4}{|c|}{ White cross-section standard errors \& covariance (d.f. corrected) } \\
\hline
\end{tabular}


(3) 38 prefectures (upper: wooden housing, lower: non-wooden housing) 住宅部分の家賃における割合分析 (木造住宅_その他38道県)

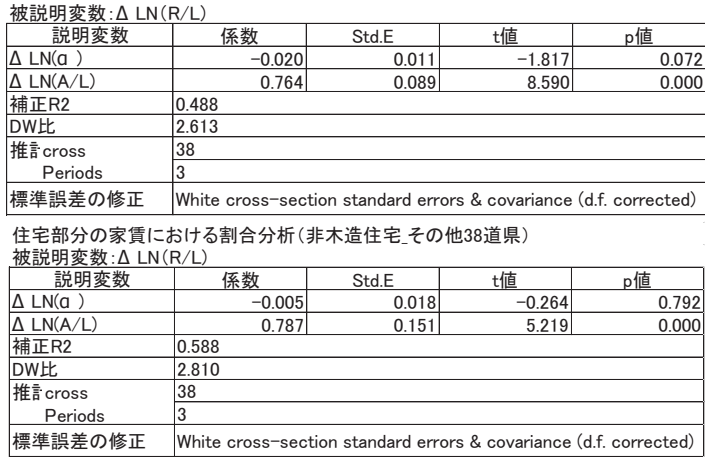

\section{3. 住宅の経年減価の推計}

以下では、まず住宅土地統計の家賃データから、（13)式を用いて 民営借家の家賃経年減価率（=家貨のうち住宅価格に帰属する部分 $y_{1} \times$ 住宅の経年減価率 $x_{A}$ ) を算出し、2 章で推計した $y_{1}$ を除す等に よって経年減価を考慮した住宅価格を求めた。その後、当該值を実 測値として、ワイブル分布に従う理論的な住宅の経年減価状況を推 計した。ここで家貨データは上述の通り住宅土地統計から取得でき るが、都道府県別の統計では入居時期については分類されていない。 清水 ${ }^{13}$ ) によると住宅賃料（家賃）には粘着性があり、その割合は 日本が米国に比べて高いという結果になっている注 ${ }^{11}$ 。 。家賃の粘着 性とは契約を継続した場合における家賃の安定性のことであり、粘 着性が高い場合には入居時期によって家賃に差が出てくることにな る。ところで、都道府県別の住宅土地統計の他に全国版の統計があ り、全国版の統計では入居時期による違いがわかるデータがある。 それを検証することで、入居時期の違いと家賃との関係を確認した。 1981 年から 1990 年までに建築された住宅における家貨は入居時期 によって幅がある（尖度が-1.2）ものの、その他の建築時期の住宅 では目立った違いはない (尖度が正の值)。したがって、本論文では 家賃の粘着性がないと仮定して分析を行った。

本分析では(13)式より、自然対数を取った新築時の家賃と築 $t$ 年 の家賃の差（=家貨の経年減価）を、2 章で推計した住宅価格に帰 属する部分の割合で除した後に逆対数を求め、新築時の住宅価格を 1.0 とした時の築 $t$ 年の（経年減価した）住宅価格の実測值とし、 住宅の経年減価の状況として考察を行った。ここで築年数について は以下のように仮定した。都道府県別の住宅土地統計の建築時期の 区分注 $\left.{ }^{12}\right)$ は各年の統計ごとに異なり、平成 10 年統計では 6 区分、 平成 15 年統計では 8 区分、平成 20 年統計では 8 区分、平成 25 年 統計では 9 区分となっている。建築時期の各区分は 3 年から 10 年 の幅があるが、区分内の詳細においては上述の通り不明である。そ こでここでは各建築時期の区分の中心年（例えば、1996 年〜2000 年の場合は 1998 年) に建築されたものとする。このように仮定し た場合、築年数の差は建築時期の区分ごとの中心年の差として分析 することになる。ところで、住宅の経年減価は加藤 14) や小見・栗 田 ${ }^{15}$ ) 等によりワイブル分布に従うと推測されている。そこで本分 析においても住宅の経年減価はワイブル分布に従うものと仮定し、 築 $t$ 年の住宅価格の理論值を以下のように定式化した。

$$
A_{t}=\operatorname{EXP}\left(-(t / \eta)^{m}\right)
$$

ここで $A_{t}$ は築 $t$ 年の住宅価格、 $m$ はワイブル係数（形状パラメー タ)、 $\eta$ は尺度パラメータである。なお、(16)式の $m$ 及び $\eta$ は未知 数であるが、本分析ではワイブルプロット注13) による方法を使って、 上記の家顀データ等から推計した住宅価格の実測值と築年数を用い て最小二乗法により $m$ 及びゥを特定した。なお、平成 10 年統計、 平成 15 年統計、平成 20 年統計、平成 25 年統計それぞれについて も、ワイブルプロットを使って住宅価格の理論值を推計した。

日本全体についての分析結果は Table.3の通りである。

ここで $m$ に注目すると、 $m$ が 1.0 の場合は一定率で減少すること になり、1.0 を超えていると当初の減価が小さく、徐々に大きくな った後に一定率で減価していく形になる。Table3 より、9 都府県以

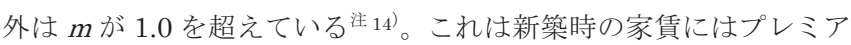
ムが付加されていることから、その分経年減価が緩やかになるもの の、当該プレミアムは築年数とともに消滅していくことが推測され る主 15)。一般に通常の住宅の経年減価では家賃のそれとは違い、中 古住宅として売却をする場合には市場においてこの種のプレミアム は剥げ落ちてしまうことが推測される。したがって、家賃から推計 した住宅の経年減価状況を推計する場合には、築浅物件における家 貨のプレミアム分を割り引く必要があるが、ここでは当該プレミア ムを含んだまま分析を行った。

Table3 Japanese age depreciation about housing managed appropriately

\begin{tabular}{|c|c|c|c|c|c|c|c|}
\hline & \multicolumn{6}{|c|}{ 日本 } & \multirow{3}{*}{ 米国 } \\
\hline & \multicolumn{2}{|c|}{ 全体 } & \multicolumn{2}{|c|}{ 住宅＜土地 } & \multicolumn{2}{|c|}{ その他 } & \\
\hline & 木造 & 非木造 & 木造 & 非木造 & 木造 & 非木造 & \\
\hline $\mathrm{m}$ & 1.32 & 1.24 & 1.29 & 0.96 & 1.33 & 1.36 & 0.71 \\
\hline$\eta$ & 52.39 & 75.79 & 67.13 & 103.24 & 48.14 & 64.83 & 144.74 \\
\hline 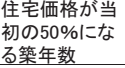 & 39.67 & 56.34 & 50.56 & 70.59 & 36.56 & 49.50 & 86.22 \\
\hline
\end{tabular}

Table3 より、日本全体の平均では、木造住宅の場合に価格が半減 するのは築 39 年で、非木造の場合には築 56 年である。競争が激し い地域の 9 都府県の場合、木造では築 50 年で、非木造では築 70 年 で住宅価格が半減する。9 都府県以外の道県（38 地域）の場合、木 造では築 36 年で、非木造の場合には概ね 50 年で住宅価格が半減す る。しかし、いずれもクー／佐々木 $\left.{ }^{6}\right)$ の分析結果のように築 15 年 で住宅価格が「0」となるようなことはない。

Fig.2 はワイブルプロットを使って推計した住宅価格の経年減価 状況の実測值と理論值（曲線）をグラフに表したものである。Fig.2 (1)より、全体として年を追う毎に住宅価格が半減する築年数は遅く 見積もられるようになっていることが窥える。ここでは特に非木造 住宅で顕著にその傾向がみられる。しかし、これは 9 都府県以外の 38 道県の非木造住宅の傾向を反映したものであり、9 都府県の非木 造住宅においては時系列で顕著な違いは見られない（Fig.2 (2)右)。 他方、木造住宅については 9 都府県及び 38 道県ともに年を追う毎 に住宅価格が半減する築年数は遅く見積もられるようになっている。 但し、38 道県の木造住宅は年を追う毎に改善はしているものの、相 対的に住宅価格が半減する築年数は他に比べてはやい (Fig.2 (3)左)。

以上から、前掲国土交通省 2) の「築 30 年を超える築古の賃貸住 宅であっても、実際の賃貸住宅市場においてはその使用価值を認め て市場価值が付いている」という見解は正しく、日本においても「リ 
フォーム等により手をかけた」と市場が認識している住宅であれば、 築古であっても「適切に評価」されるものと推測できる。

ここまでは日本の住宅価格に関して経年減価状況を考察したが、 本論文では米国の住宅についても経年減価状況を分析した。US Department of Commerce ${ }^{16)}\lceil$ American Housing Survey」では、 米国の築年別の住宅価格が取得できることから、1987 年から 2007 年までのデータ (隔年統計) を利用注 ${ }^{16}$ ) し、Standard \& Poor's ${ }^{17}$ ) 「S\&P ケースシラー住宅価格指数」で実質化注 ${ }^{17)}$ して、ワイブルプ ロットで米国住宅のワイブル係数 $m$ 及び尺度パラメータ $n$ を特定 した。

分析の結果、米国の住宅価格の経年減価状況を示寸ワイブル係数 $m$ は 0.708 で、尺度パラメータ $n$ は 144.740 であった。 $m$ が 1.0 よ りも小さいことから、当初の減価が大きく、徐々に小さくなった後 に一定率で減価していく形になる。つまり、中古住宅として売却を する場合には新築住宅としてのプレミアムが（既に「新築」ではな いことから）剥げ落ちてしまうために築浅で売却する場合の減価が 大きくなるが、その後は当該プレミアムが消滅しているので、経年 による減価だけの状態になるものと推測することができる。
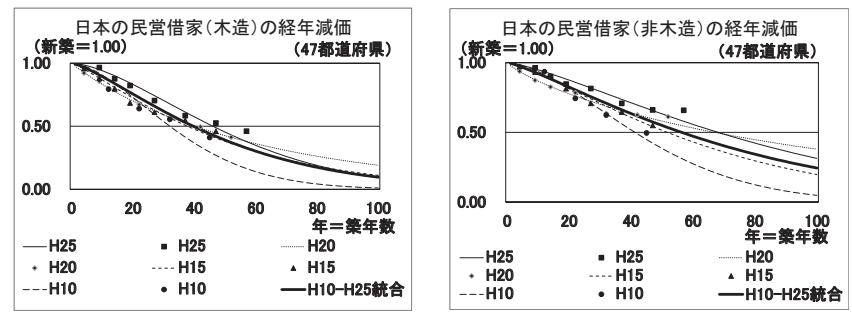

(1) All Japan (left: wooden housing, right: non-wooden housing)
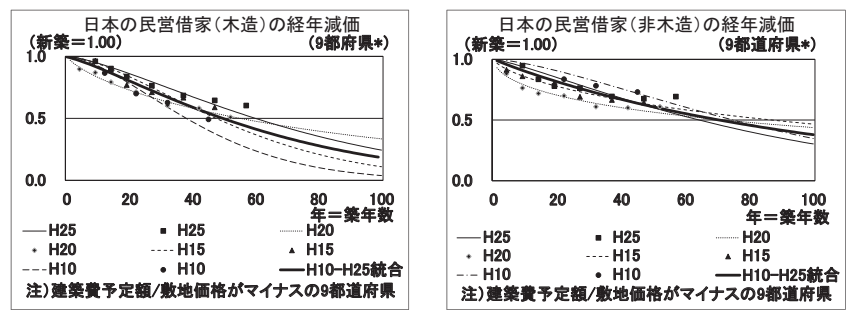

(2) 9 prefectures (left: wooden housing, right: non-wooden housing)
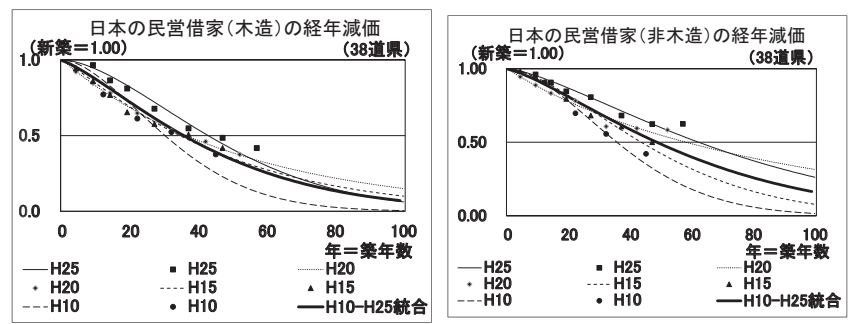

(3) 38 prefectures (left: wooden housing, right: non-wooden housing)

Fig. 2 Situations in Japan about a life of housing with the Weibull distribution

Fig.3（1)は米国住宅の減価の実績值と理論值（曲線：1987 年〜 2007 年の平均值）を示したものである。これによると住宅価格が半 減するのは築 86 年である。Fig.3 (2)は米国住宅の経年減価状況（理 論值）と 9 都府県の木造及び非木造の状況（理論值）を並べたグラ
フである。Fig.3 (2)より、当初の住宅価格の低下速度は米国住宅の 方がはやいものの、概ね 25 年くらいで逆転していることがわかる。 これは上述の通り米国の推計では住宅そのものの経年減価状況を観 測したので、中古住宅として売買される住宅では築浅物件程プレミ アム分が大きいためだと推測できる。他方、本分析では家貨から住 宅の経年減価状況を推計しているために、家賃には新築のプレミア ムが 20 年くらいまで残るので、このような現象が観測されるもの と推測できる。したがって、新築のプレミアムを考慮すると、日本 の経年減価状沉は Fig.3 (2)よりも悪化しているはずである。

以上から、9 都府県の住宅価格が半減する築年数は日本国内にお いては比較的遅いと推測できるが、米国に比べるとはやり住宅価格 の低下速度ははやいことがわかる注 18 )。

とはいえ、競争が激しい 9 都府県の住宅、特に非木造住宅に関し ては平成 10 年統計から一貫して住宅価格が半減する築年数は遅く 評価されていることから、米国住宅同様に「リフォーム等により手 をかけた」と市場が認識する住宅の価格については日本の住宅市場 においても「適切に評価」されているものと推測できる。

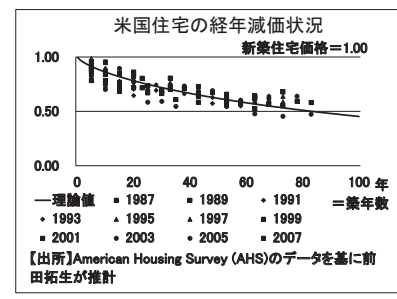

(1) US

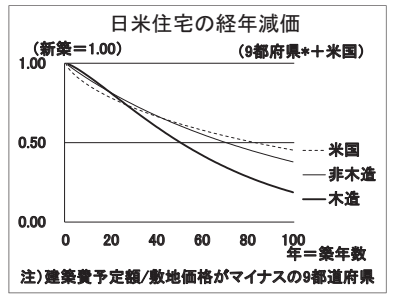

(2) US and 9 prefectures in Japan
Fig. 3 Situations in US and Japan about a Iife of housing with the Weibull distribution

\section{4. まとめ}

日本は欧米に比べて中古住宅の流通が少ない。この点に関して国 土交通省 2) は、日本では個々の住宅の本質的な価值を適切に市場が 評価するシステムが整っていないことが原因であると仮定し、「リフ オーム等により手をかけた住宅が適切に評価されるよう、築年数の みによらず、住宅の使用価值を適切に反映した評価手法への改善を 図る」ことを提言している。しかし、日本人はそもそも「経年的に 価值の減衰を避けられない」という「住宅寿命観」が存在するとい う考え方もあり、この考え方に基づくと建物評価の適正化を図って リフォーム等を促しても、住宅市場の参加者は「適正な価値」を受 け入れず、築古の住宅に対しては極めて厳しい評価になってしまう 可能性がある。

そこで本論文では、賃貸住宅の場合、一般の住宅に比べて（家顀 収入を継続的に得ていくためにも）適切に管理されているという前 掲国土交通省 ${ }^{2)}$ の認識に注目し、住宅の市場参加者も同様の認識を 持っていると仮定して賃貸住宅の家賃の経年減価を基に住宅の経年 減価を推計した。その結果を一般の住宅の経年減価状況(クー／佐々 木 ${ }^{6)}$ ) と比較することで、日本でも適切にメンテナンス等を施し管 理されていると市場が認識しているような住宅は経年による減価を 低く（住宅価格の減価する速度が遅くなると）見積もるか否かを検 証した。また、米国住宅の経年減価状況も分析し、それとも比較し 
た。

分析の結果、家賃の経年減価をもとに推計した住宅の経年減価は 一般住宅に比べて緩やか(住宅価格の減価する速度が遅い)であり、 競争が激しい地域（東京、大阪、名古屋などの大都市圈を抱える都 府県 9 地域）ほど、その傾向が強いことがわかった。しかし、競争 が激しく、住宅の経年減価が緩やかな 9 都府県でも、米国住宅の経 年減価と比較すると住宅価格が半減する築年数が短いことも同時に 明らかになった。以上から日本でも、米国住宅ほじではないものの、 「リフォーム等により手をかけた」と市場が認識しているような住 宅については、日本の住宅市場においても「適切に評価されている」 と推測することができ、住宅の使用価值を適切に反映した評価手法 への改善は効果あると考えられる。

とはいえ、本分析では家賃の経年減価から住宅の経年減価状況を 推測しているために、新築時におけるプレミアム(「新しい」という 点に関する付加的な価值づけ）が攪乱要因となっている。この点に ついては今後の課題としたい。

\section{参考文献}

1) 内閣府: 経済財政白書 平成 22 年版, 内閣府, 2010.7

2）国土交通省：中古住宅の流通促進 - 活用に関する研究会報告書, 国土交通 省住宅局住宅政策課, 2013.6

3）前田拓生：日本の既存住宅市場における問題点とその活性化に資する制 度・インフラについての考察, 高崎経済大学論集, 第 54 巻第 2 号, pp.68-79, 2011.9

4）原野啓・中川雅之・清水千弘・唐渡広志 : 情報の非対称性下における住宅 価格とリフォーム, CSIS 年報, No.94、pp.1-15, 東京大学空間情報科学研究 センター, 2009.1

5）山崎古都子：中古住宅に期待する財産価值が住宅管理に与える影響、に関 する日米比較研究, 平成 13 年度 平成 16 年度科学研究費補助金科学研 究費基盤研究 (C) (2) 研究成果報告書、2007.3

6) リチャード・クー/佐々木雅也：なぜ日本は豊かになれないのか, 知的資 産創造, 2008 年 10 月号, pp.64-81, 2008.10

7) 総務省: 住宅土地統計調査（平成 10 年、平成 15 年、平成 20 年、平成 25 年），総務省統計局 http://www.stat.go.jp/data/jyutaku/ ,2015.8.8 (参照)

8 ）総務省：平成 22 年基準消費者物価指数（CPI），総務省統計局 http://www.stat.go.jp/data/cpi/ . 2015.8.28 (参照)

9）一般社団法人土地情報センター: 都道府県市区町村別 - 用途別平均価格 · 対前年平均変動率表, 都道府県地価調查平成 25 年 平成 8 年 http://www.lic.or.jp/research/ , 2015.8.15 (参照)

10 ) 内閣府：2013 年度国民経済計算, 経済社会総合研究所、 http://www.esri.cao.go.jp/jp/sna/data/data_list/kakuhou/files/h25/h25_k aku_top.html\#c1 , 2015.8.21 (参照)

11）国土交通省：住宅着工統計調査（2011 年 1 月～2013 年 9 月），国土交 通省総合政策局 http://www.mlit.go.jp/sogoseisaku/jouhouka/ sosei jouhouka_tk4_000002.html,2015.8.18 (参照)

12）国土交通省：建設工事費デフレーター（平成 17 年度基準），国土交通 省総合政策局 http://www.mlit.go.jp/sogoseisaku/jouhouka/sosei _jouhouka_tk4_000112.html, 2015.8.18 (参照)

13）清水千弘：住宅市場の投資特性，マーケットレポート（2008 年 12 月 25 日) http://www.tokiomarine-pim.com/market/, pp.1-11, 2008.12

14）加藤裕久：住宅の寿命分布に関する調查研究 (2), 住宅総合研究財団研 究年報, No.18, pp.1-10, 1992.9

15）小見康夫・粟田紀之：長寿命化トレンドを考慮した建築残存率のシミュ レーション, 日本建築学会計画系論文集, 第 75 巻, 第 656 号, pp.2459-2465, 2010.10、

16) US Department of Commerce : National Summary Report and Tables, American Housing Survey 2007, 2005, 2003, 2001, 1999, 1997, 1995, 1993, 1991, 1989, 1987, US Census Bureau

17) Standard \& Poor's : S\&P/Case-Shiller Home Price Indices, S\&P Dow Jones Indices http://us.spindices.com/about-sp-indices/, 2015.8.18(accessed)

注

注 1） 2013 年データ（国土交通省 ${ }^{2}$ 作成）では既存住宅の取引シェアは米国 $83.1 \%$ 、英国 $88.0 \%$ 、日本 $14.7 \%$ 。

注 2) 内閣府 1) では、日本で既存住宅市場が未発達である背景の一つとして 「供給側では対象となる住宅ストックそのものの不足や質に関する情報不 足」（p.258）を挙げ、50 年以前の住宅ストック数に着目し、日本では「住 宅の『寿命』ともいうべき滅失住宅の平均築後年数が短い」（p.259）と指 摘している。なお同注（33）で「我が国（日本）では、滅失住宅の平均築 後年数は 30 年にとどまっているが、アメリカでは 55 年、英国では 77 年」 （p.259、（）内は筆者加筆）と明記している。

注 3）原野・中川・清水・唐渡 ${ }^{4}$ p. 14 引用。（）内は筆者加筆。なお、原 野・中川・清水・唐渡 4) では、情報の非対称性が存在すると考えられる日 本の既存住宅市場においてのリフォームと住宅価格の関係を分析している。 注 4) 山崎 ${ }^{5)}$ p.67 引用。

注 5) 住宅賃料についての建築後年数の価格減価については清水 13$)$ で取り扱 っているが、住宅そのものの経年減価は取り扱っていない。

注 6）住宅土地統計調查の標本誤差については「平成 25 年住宅・土地統計調 查利用上の注意 http://www.stat.go.jp/data/jyutaku/2013/riyou.htm」を 参照。

注 7）住宅着工統計では「貸家」しか分類されていないので、公営または民営 の区別はされていない。

注 8）後述の住宅価格に関する統計（住宅土地統計によるもの）では「戸建 長屋建」の区別がなく、戸建と長屋建を合計した值しか存在しないことか ら、ここでもそれに合わせて戸建と長屋建を合計した值を使用した。

注 9）このデータは貸家に特化したものでないことから、工事費予定額は若干 高く出ることが予想される。両データに関して定数項を 0 として回帰分析 したところ、木造住宅では 7\%、非木造住宅で $5 \%$ 高く出ている。

注 10）大都市圏を含む 9 都府県。具体的には埼玉県、千葉県、東京都、神奈 川県、静岡県、愛知県、京都府、大阪府、兵庫県。

注 11）清水 ${ }^{13)}$ pp. $6-7$ 参照

注 12）以下の区分については除いている。平成 10 年統計では終戦前 $(1945$ 年以前）、平成 15 年統計では昭和 25 (1950 年) 以前、平成 20 年統計で は昭和 25 (1950 年) 以前、平成 25 年統計では昭和 25 (1950 年) 以前。 注 13） $t$ 期までに累積した滅失住宅率を $F_{t}$ とすると、 $F_{t}$ は下記のように表す ことができる。

$$
F_{t}=1-A_{t}
$$

これは(6)式から下記のように書き換えられる。

$$
F_{t}=1-\operatorname{EXP}\left(-(t / \eta)^{m}\right)
$$

この式からワイブル係数 $m$ と尺度パラメータ $n$ を求めるために下記のよ うに変形する。

$\mathrm{LN}\left(\mathrm{LN}\left(1 /\left(1-F_{t}\right)\right)=m \cdot \mathrm{LN}(t)-m \cdot \mathrm{LN}(\eta)\right.$

$\mathrm{LN}\left(\mathrm{LN}\left(1 /\left(1-F_{t}\right)\right)\right.$ を被説明変数、 $\mathrm{LN}(t)$ を説明変数として回帰分析すれ ば、 $m$ を推計することができ、 $\eta$ も算出することができる。

注 14）平成 10 年及び平成 25 年統計の非木造の $m$ は 1.0 を超えている。 注 15）前掲清水 ${ }^{13)}$ によると、特に非木造住宅の場合には入居後 5 年で $6 \%$ 程 度の大幅な家賃の低下が観測され、その後築 20 年くらいかけて減価率が一 定化してくるという結果となっている。

注 16) 2007 年から後の統計では当該データが取得できない。

注 17) S\&P/Case-Shiller Home Price Indices Composite-10 を使用した。 注 18）そういう意味では米国に比べて日本では「住宅寿命観」が存在してい る可能性がある。 


\section{A CONSIDERATION ABOUT AGE DEPRECIATION OF HOUSING IN JAPAN}

A projection based on statistics of age depreciation of rent in commercial rental housing

\section{Takuo MAEDA*}

* Adjunct Researcher, Waseda-University Research Institute for Science and Engineering, MBA

Japanese market of existing housing is fairly quiet and inactive in comparison to those markets in other developed countries. The Ministry of Land, Infrastructure, Transport and Tourism (2013) pointed out that a lack of proper feedback system cause the market to evaluate only legal residual value of resale properties rather than intrinsic value of resale housing in Japan. They are proposing that an evaluation system needs to reflect not only the age of building but also quality of maintenance and retrofit and properly estimated economic life of housing. However, Yamazaki (2007) argues that most Japanese accept a notion that the housing asset decreases as they age, despite of maintenance and retrofit. Based on this perspective, Japanese buyers might not accept the proposed economic life of housing discussed above, and stick to a notion that housing value would decrease with time regardless of new evaluation system.

According to Koo-Sasaki (2008), housing of Japan loses all the value in about 15 years old. Thus a life of housing in Japan is very short, many owners of Japanese housing do not work hard to raise their housing value. However it is necessary to make it clear whether most Japanese recognize that housing value decreases with time, even if the owner of housing works hard to raise its value. By the way, even in Japan, a lot of rental housing are managed properly because it is necessary to maintain their housing value in the market. We thought that the estimated rate of age depreciation in Japan would be about the same between privately owned housing managed well and rental housing. Therefore at first we divided contribution to a rent for rental housing into the land and building by performing a regression analysis of pooled data with using the Housing and Land Survey in the Statistics Bureau of the Japanese government. Based on the result, we estimated age depreciation of asset in commercial rental housing in Japan after we estimated age depreciation of rent in commercial rental housing. This was regarded as age depreciation of properly managed housing. We tried to clarify whether a life of well managed housing is longer than privately-owned properties in Japan. We analyzed the situation about a life of housing with the Weibull distribution related to housing destruction probability distributions. In addition, we compared our analysis in Japan with average housing in US based on resources from American Housing Survey in the US Census Bureau.

As a result of analysis from a projection of age depreciation of rent, age depreciation rate of rental housing was more gradual than privately owned housing. In other words, a service life of rental housing was longer than a service life of non-managed average housing. This tendency was especially true in a metropolitan area like Tokyo, Osaka, Nagoya and so on. It also became clear that a service life of housing in the Japanese metropolitan area, even though the age depreciation rate is more gradual in those area, is shorter than those in the United States.

As described above, we could say that privately owned housing with proper maintenance and retrofit could have extended service life, if many Japanese recognize in resale housing market the value of proper care of their houses and that the care could increase their houses' economic value. Thus the system being established by the Ministry of Land, Infrastructure, Transport and Tourism (2013) would be effective in increasing sales volume of secondhand housing market and extending a service life of housing in Japan. 